\title{
Does microcredit use helps farmers win battle against food insecurity: evidence from Jimma zone of Southwest Ethiopia
}

\author{
Amanuel Berhanu', Abayineh Amare ${ }^{1 *}$, Birki Gurmessa', Yadeta Bekele ${ }^{2}$ and Tamiru Chalchisa ${ }^{1}$
}

\begin{abstract}
Background: Lack of access to credit precludes smallholder farmers from making investment that generates greater level of income, consumption and wealth. To reverse this limit, Oromia Credit and Saving Share Company has been providing microcredit for rural households for the last two decades in the study area. Yet, there is limited knowledge on the impact of this microcredit service on rural household food security in Jimma zone. Therefore, this research aims at generating location-specific data on the impact of microcredit utilization on household food security in the study area. A multistage sampling procedure was employed to select 360 sample households. Data were generated through household survey, focus group discussion and key informant interview. Both descriptive and econometric data analysis techniques (binary logit model and Propensity score matching) were used.

Results: The results reveal that educational level, family size; land size and non/off-farm income of the households influenced microcredit utilization positively, whereas livestock ownership and farm income negatively influenced it. The analysis of food security status indicate that large proportion of households are food secure. The Propensity score matching result expose that microcredit utilization has generated a positive and significant impact on household food security.
\end{abstract}

Conclusions: Efforts towards scaling out services of microcredit institutions should target improving financial literacy of the rural poor and their current financial need on the basis of other resources such as land and livestock they owned with the ultimate goal of ensuring household food security. It is also imperative to realize the labour force capacity of the households in the process of expanding credit service.

Keywords: Impact, Food security, Microcredit, Propensity Score matching, Ethiopia

\section{Background of the study}

The fundamental challenge facing the world today is ensuring millions of households living in poverty to have access to enough food to maintain a healthy life. About 805 million people throughout the world and particularly in developing countries do not have enough food

\footnotetext{
*Correspondence: abaytana82@gmail.com

${ }^{1}$ Department of Rural Development and Agricultural Extension, Jimma University College of Agriculture and Veterinary Medicine, P.O.Box 307, Jimma, Ethiopia

Full list of author information is available at the end of the article
}

to meet their basic needs [1]. In Africa, about 239 million people are undernourished [1]. The worsening of the food security situation in Africa seems to be exacerbated by the diffusion of rural poverty. In fact, considering that the majority of the Ethiopian population are rural inhabitants, often they do not produce sufficient food and do not have sufficient purchasing power to cover their food needs [2].

It is estimated that over $90 \%$ of agricultural production is from rural farm households with little access to productive resources to adopt improved technologies that will enhance food production [3]. It is also frequently original author(s) and the source, provide a link to the Creative Commons licence, and indicate if changes were made. The images or other third party material in this article are included in the article's Creative Commons licence, unless indicated otherwise in a credit line to the material. If material is not included in the article's Creative Commons licence and your intended use is not permitted by statutory regulation or exceeds the permitted use, you will need to obtain permission directly from the copyright holder. To view a copy of this licence, visit http://creativecommons.org/licenses/by/4.0/. The Creative Commons Public Domain Dedication waiver (http://creativeco mmons.org/publicdomain/zero/1.0/) applies to the data made available in this article, unless otherwise stated in a credit line to the data. 
noted that the lack of liquidity, as well as the low degree of access to formal and informal credit are major problems [4]. Ethiopia is one of the most food-insecure and famine-affected countries. According to Government-led multi-agencies assessment, 10.2 million Ethiopians are considered to be food insecured in 2015/16 [5].

The provision of micro-credit is one of the important economic inputs in the effort to reduce poverty and food insecurity and empowering economically marginalized segments of the society Abdul-Jalil, Agbola et al., Karlan and Zinman, Sadick et al. [3, 6-8]. Karlan and Zinman [7] found that microloans increase ability to cope with risk, strengthen community ties, and increase access to informal credit. Similarly, Agbola et al. [6] found that microfinance has had a mildly positive impact on poverty reduction through increases in income and savings. Mounting evidence suggested that access to credit helps farmers to purchase improved inputs and agricultural equipment that would potentially contribute to increased agricultural productivity [3]. Even though, credit utilization has positive impact on the food security of the households of area under study, the households have faced a number of challenges related to credit utilization. For instance, high interest rate, lack of collateral security to receive loan, low amount of loan provided from microfinance's, short repayment period and delay in approval or disbursement are the major constraints of credit utilization in the area under study.

The smallholder farmers' subsistence nature of agricultural practices, and their on-farm and off-farm activities are usually small scale which leads to yield little income. Therefore, they are not able to invest in improved production technologies that will increase food productivity [9]. In Ethiopia, microfinance was introduced in 1996, with the government's declaration of the Proclamation No. 40 in June 1996 that facilitated several sustainable Microfinance institutions to flourish [10]. Currently, there are 35 microfinance institutions registered with the National Bank of Ethiopia which provides microfinance service to approximately 2.5 million active borrowers [11]. Oromia Credit and Saving Share Company is one of the microfinance institutions that was established in August 1997 as per the commercial code of the country and with the proclamation No.40/1996 [12]. It is one of the major providers of agricultural credit and saving services for the rural population in the area under study [13].

Since the launching of microfinance institutions in Ethiopia, some studies were conducted on determinants to access microcredit, the role of microfinance in socioeconomic aspects, impact and effectiveness on household income and livelihood diversification. In this context, microfinance institution is defined as a type of financial institution that provides financial service to the poor peoples, unemployed or group of peoples who have no access to financial services of commercial banks [14]. For instance, Getaneh [15]; Siyoum et al. [16]; and Deribe et al. [17] noted that microcredit is a good strategy to mitigate poverty and creates an opportunity for the marginalized segment of the population in creating access to finance. Sida [18] also posited that the provision of credit to farmers is the best remedy to complement the on-farm and the off-farm income of smallholder farmers to enhance food production. Dereje et al. [19] contended that the provision of credit to farmers is widely perceived as an effective strategy for promoting the adoption of improved and risky technologies through the relaxation of the financial constraint as well as through the boosting of households risk-bearing ability.

In the same vein, several studies were conducted in Oromia Regional State on microfinance. For instance, some of these studies include: determinants of women's participation in microfinance services [20], impact of microcredit utilization on household's income [21], factors affecting credit use for rural farming at household level [22], the role of microfinance institution in women's household decision making [23], the outreach and financial performance of microfinance institution [24], the role of microfinance institutions in improving livelihood [18], the role of Credit and Saving share Company in poverty reduction in rural communities [25], are some examples. The core finding of the above studies disclose that microfinance institutions have an explicit potential to improve the livelihood of households. However, the critical evaluation of these studies informed us the empirical knowledge they generated on the impact of microfinance institutions' on household food security is thin.

Overall, although micro-credit is claimed to support household food security, there is little systematic analysis in the literature that explains factors that facilitate/ constrain to micro-credit utilizations and the potential food security benefits it generates. Hence, the study aims to generate empirical evidence that inform policymakers of the potential benefits microcredit institutions generate for household food security. The general objective of the study is to examine factors that determine credit use and assess the impacts of microcredit utilization on household food security in Jimma zone, Southwest Ethiopia.

\section{Methods and materials Description of the study area}

The study was conducted in three randomly selected rural administrative woredas of Jimma zone. Jimma zone is one of the 18 zones of Oromia Regional State located to the Southwest of Ethiopia, at a distance of $352 \mathrm{~km}$ from the capital city of the country; Addis Ababa. The zone has 21 rural woredas with a total population of 2,780,549 
[26] living in 543 kebeles. The three rural administrative woredas were chosen to assess the determinants of microcredit and its impacts on food security. These three woredas were selected randomly using lottery methods and they were Omo nada, Seka chokersa, and Goma woredas. The three microfinance institutions in Jimma zone: namely, Oromia Credit and Saving Share Company (OCSSCO), Ishet Microfinance and Harbu microfinance institutions.

Gomma Woreda is one of the 21 woredas in Jimma zone known for its predominant coffee production.. It is located $403 \mathrm{~km}$ southwest of Addis Ababa and about $50 \mathrm{~km}$ west of Jimma town. One of the coffee biodiversity centres in Ethiopia is found in this Woreda. The woreda consists of 39 rural and 3 Urban Kebeles. The number of agricultural households in the Woreda was 45,567 $(35,533$ male-headed (78\%) and 10,034 female-headed $(22 \%)$, while the total population of the Woreda was 216,662 of which 110,448 are males and 106,174 females [26]. Gomma is the second most densely populated Woreda in Jimma zone with a size of $96,361.72$ ha (94.4 $\mathrm{km}^{2}$ ) including the two coffee state farms which cover an area of 2704 ha [26]. The average annual rainfall of the district is $1524 \mathrm{~mm}$ with low variability. Its rainfall distribution is bimodal in which the small rains occur from March to April and the main rainy season starts from June to October. Consequently, crop and livestock production is not constrained by the amount and distribution of rainfall. Altitude in Gomma ranges from 1387 to $2870 \mathrm{~m}$ above sea level (masl). Most parts of the Woreda lay between 1387 and 1643; and 1849 and 2067 masl. tje soils types are young and generally acidic in nature.

Seka Chekorsa, one of the woredas in Jimma zone, lies in the South Western part of Jimma town. It has 34 rural Kebeles and 2 urban Kebeles. The area has a total population of 258,100 . Within the total population, 9,138 are in urban and 248,962 are in a rural area of which about $(124,166$ female) and (124,796 are male). Out of the urban (9138) population, 4759 are female and 4,379 are male. Within the total population, the compositions of young, economically working and adult age are $45.6 \%, 51.5 \%$, and $2.9 \%$, respectively [26]. Topography of this district ranges from gently sloping to hilly lands with ridges and valleys in between. Seka Chekorsa is located at $18 \mathrm{~km}$ away from Jimma town and bordered on the south by the Gojeb River that separates it from the Southern Nation Nationalities and Peoples Region (SNNPR); it is bordered on the west by Gera; on the northwest by Gomma; on the north by Mana; on the northeast by Kersa; and on the east by Dedo woredas. Altitudinal the district extends between 1580 and 2560 masl. The mean annual rainfall and temperature of the district ranges $1633-1769 \mathrm{~mm}$ and $16-200{ }^{\circ} \mathrm{C}$, respectively) Gojeb, Abono, Gibe, Anja,
Gulufa and Meti perennial rivers, as well as Harsu and Busho Seasonal streams, are flowing through the district. Major soil types found in Seka Chokorsa are Pellic Vertisols, Orthic Acrisols and Dystric Nitosols. High Forest, Woodland, riverine and man-made forests are available in the district. For example, Belete Gera forest $(37,417 \mathrm{ha})$ is under government protection in this district [27]. The total surface area of the district is $96.4 \mathrm{~km}^{2}$. The rainy season extends from February to September with the highest rainfall usually recorded in August. The soil type is dark reddish-brown and the wide area of the Woreda is covered with vegetation [27].

Omo Nada woreda is located $290 \mathrm{~km}$ southwest of the capital Addis Ababa and found $72 \mathrm{~km}$ east of Jimma town. It has 20 rural and 3 urban kebeles. It is bordered on the south by the Gojeb river which separates it from the SNNPR, on the west by Dedo woreda, on the northwest by Kersa woreda, on the north by Tiro Afeta woreda, on the northeast by Sokoru woreda, and on the east by the Omo River which separates the district from the SNNPR. Nada is the capital of the Omonada woreda. Omo Nada woreda lies at $7^{\circ} 17^{\prime}$ to $7^{\circ} 49^{\prime} \mathrm{N} 37^{\circ} 00^{\prime}$ to $37^{\circ}$ $28^{\prime}$ E. According to the Central Statistical Agency report of 2007 [26], the population of the woreda was estimated to be 254,417 . The rainfall of the area is bimodal, with unpredictable short rains from March to April and the main rainy season from June to September. The minimum and maximum annual rainfall ranges from 1066 to $1200 \mathrm{~mm}$ with a mean annual temperature variation from 18 to $25^{\circ} \mathrm{C}$ [26]. The area is characterized by gentle, flat and undulating topography with the altitude ranging from 1650 to 2200 m.a.s.l. The land cover categories of the woreda comprise $26.5 \%$ potential arable or cultivable land which includes $23.4 \%$ annual crops and $7.0 \%$ pasture and $56.6 \%$ forest land and the remaining $9.9 \%$ was classified as degraded, built-up or otherwise unusable. Figure 1 depicts the map of the study zone and sampled woredas.

\section{Research design, sampling techniques}

The research design for this particular study was mixed methods of cross-sectional survey with both qualitative and quantitative components. Multi-stage sampling procedures were used to select sample respondents. In the first stage, three rural administrative woredas were selected randomly by lottery method from 21 rural woredas of Jimma zone. In the second stage, two kebeles from each woreda, a total of six kebeles from all three woredas, were selected using a simple random sampling technique. Then, households from each sampled kebeles were stratified into microcredit users and non-users groups based on their participation in credit. The households included in microcredit users' stratum were those who had at least 3-year participation status 


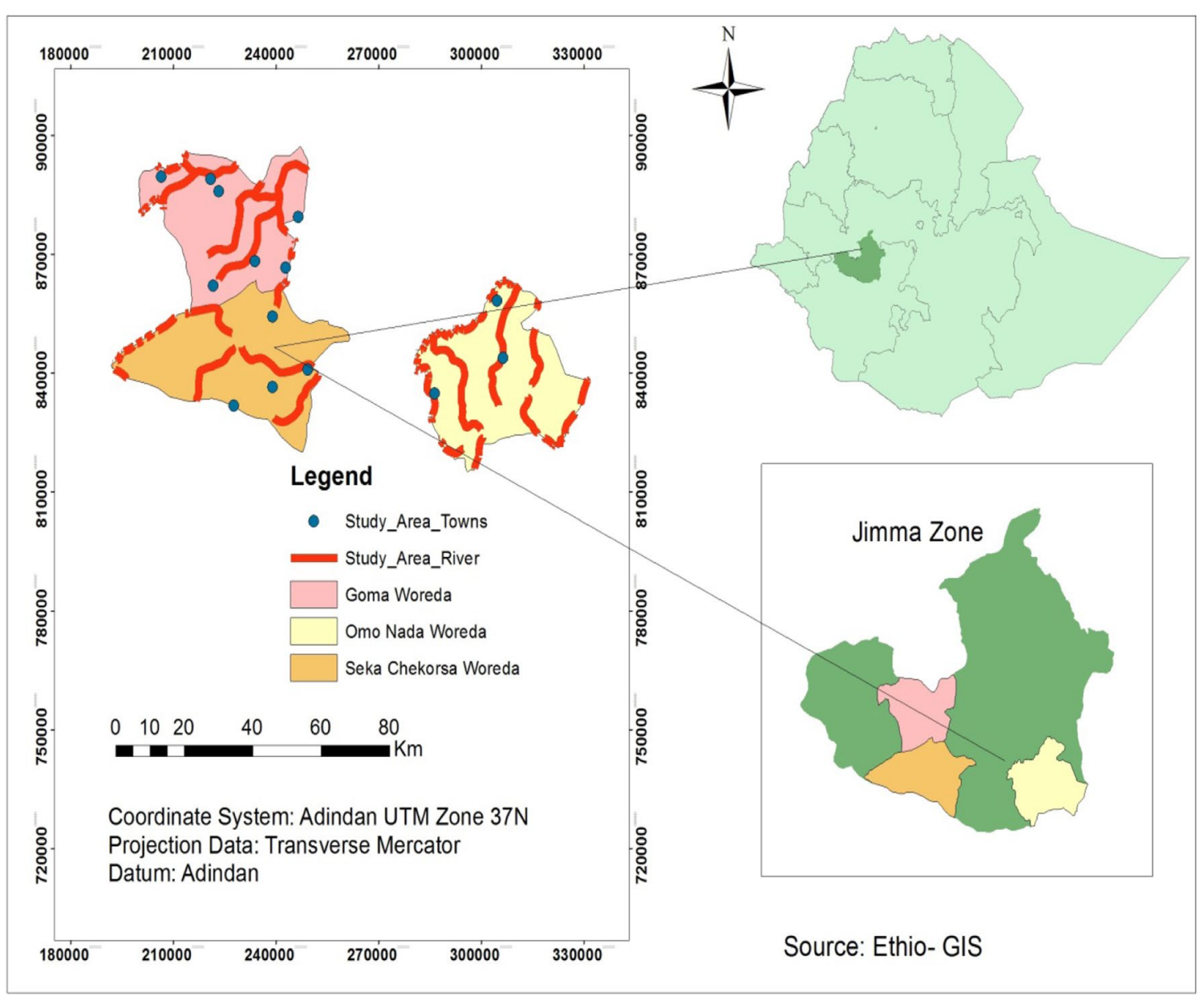

Fig. 1 Map of the study area (Source: Ethio-GIS)

in OCSSCO microfinance institution and non-users group, otherwise. Finally, using simple random sampling procedure and probability proportional to size, 360 sample households were selected from both user and non-user groups. The sample size was determined by applying Kothari [28] sample size determination formula:

$$
\begin{aligned}
& n=\frac{Z^{2} p q N}{e^{2}(N-1)+Z^{2} p q} \\
& n=\frac{(1.96)^{2} 0.5 * 0.5 * 5710}{(0.05)^{2}(5710-1)+(1.96)^{2} * 0.5 * 0.5}=360
\end{aligned}
$$

where $n$ is the sample size; $N$ is the total population (5710); $Z$ is the $95 \%$ confidence interval under normal curve (1.96); $e$ is the acceptable error term (0.05) and $\mathrm{p}$ and $\mathrm{q}$ are estimates of the proportion of population to be sampled ( $p=0.5$ and $p+q=1)$. Accordingly, the sample size for the study was determined as follows: the total populations of the six Kebeles' are 5710 (which 2735 credit users and 2975 non-users), respectively (Table 1).

\section{Data types and sources}

Both quantitative and qualitative data were gathered from primary and secondary sources. Primary data was collected from the study participants, while secondary data were gathered from various documents both published and unpublished materials that are relevant to the study.. Demographic, socio-economic and institutional related variables relevant to the study such as sex of the household, age of the household head, religion, marital status, educational level, family size, farming experience, land size, livestock holding, on-farm income, frequency of extension contact, time required to reach micro-credit institution and off-farm income were collected Besides, qualitative data on the types of food consumed by households were collected. 
Table 1 Distributions of sample respondents in each kebele. Source: own summary, 2019

\begin{tabular}{|c|c|c|c|c|c|}
\hline \multirow[t]{2}{*}{ Woredas } & \multirow[t]{2}{*}{ Kebeles } & \multicolumn{2}{|c|}{ Total number of households } & \multicolumn{2}{|c|}{ Sampled households } \\
\hline & & Credit user & Non user & Credit user & Non user \\
\hline \multirow[t]{2}{*}{ 1. Omo Nada } & Waktola & 340 & 360 & 21 & 23 \\
\hline & Nada Cala & 450 & 470 & 28 & 30 \\
\hline \multirow[t]{2}{*}{ 2. Goma } & Buko & 560 & 573 & 35 & 37 \\
\hline & Bulbulo & 526 & 542 & 33 & 34 \\
\hline \multirow[t]{2}{*}{ 3. Seka Chekorsa } & Shashamane & 448 & 524 & 28 & 33 \\
\hline & Ula Uke & 411 & 506 & 26 & 32 \\
\hline Total & & 2735 & 2975 & 171 & 189 \\
\hline
\end{tabular}

\section{Methods of data collection}

Primary data were collected through various data collection instruments, such as a household survey using a structured questionnaire, Focus Group Discussion (FGDs) and key informant interviews (KII). The household survey covered personal data, household resources, production, food consumption and income, and issues related to credit utilization and food security. The questionnaire was first prepared and pre-tested on 20 households to check and make some corrections. Six enumerators, one for each kebeles were selected based on their ability of local language and culture, and their prior experiences on data collection. The training was given to the enumerators on the content of the questionnaire and procedure to be followed while interviewing the respondents.

FGDs were held to supplement the individual respondent's. Two focus group discussions were conducted at each study kebeles and each FGD comprised eight individuals. The output of the discussion was used to get additional supporting qualitative evidence on the current situation of household for food security, the purpose of microcredit utilization and challenges that farmers have faced on credit utilization. In addition, four experts from each Oromia Credit and Saving Share Company and agricultural and rural development office, three development agents and four community members (two men and two women) from every six kebeles were included as key informants.

\section{Methods of data analysis}

The data were analyzed using descriptive statistics and econometric models. Descriptive statistics such as mean, standard deviation, frequency, and percentage were used to analyze the socio-economic characteristics of the sampled respondents. In addition, Chi-square and $t$ test were used to test the statistical significance of the dummy and continuous independent variables, respectively. It is noted that this research has two specific objectives. Each objective needs specific data analysis methods. On the basis of this, a binary logistic regression model was used to identify major determinants of microcredit utilization. Propensity score matching was employed to evaluate the impact of microcredit utilization on rural household's food security. Moreover, qualitative data collected from focus group discussions and key informants were analyzed by narrative explanations. Overall, the quantitative analysis was done using SPSS ver. 20 and STATA ver. 13).

\section{Econometric model specification}

A binary logistic regression model is a proper model when the dependent variable is a dummy one consisting, 0 and 1 [29]. It is commonly argued that logit and probit models are usually used to establish the relationship between household characteristics and the dichotomous response variable (credit users and non-user). The advantage of these models over the linear probability model is that the probabilities are bound between zero and one. Moreover, the best fit the nonlinear relationships between the response and the explanatory variables. The models specify a functional relationship between the probabilities of being credit users and various explanatory variables. In principle, one can substitute the probit model for logistic model, as their formulations are quite comparable; the main difference is that the logistic model has slightly fatter tails than the cumulative normal distribution, i.e., the probit curve approaches the axes more quickly than the logistic curve [29]. Hence, the binary logistic model is selected for this study.

$$
P_{i}=\mathrm{E}\left(Y=1 / X_{i}\right)=\frac{1}{1+e^{-\left(\beta_{o}+\beta_{1} X_{i}\right)}}
$$

For ease of exposition, Eq. (1) can be expressed as

$$
P_{i}=\frac{1}{1+e^{-Z_{i}}}
$$

where $Z_{i}=\beta_{0}+\beta_{j} X_{j i}, \quad \forall j \in V, \forall i \in \mathrm{N}$. 
Where $V$ is a set of explanatory variable and $N$ is the set of all observations.

If $P_{i}$ is the probability of being user of microcredit, then the probability of non-user of microcredit is given by $1-P_{i}$, which is expressed as follows:

$$
1-P_{i}=\frac{1}{1+e^{Z_{i}}}
$$

Therefore, this can be written as

$$
\frac{P_{i}}{1-P_{i}}=\frac{1+e^{Z_{i}}}{1+e^{-Z_{i}}}=e^{Z_{i}}
$$

where $P_{i} /\left(1-P_{i}\right)$ is simply the odds ratio in favor of microcredit user; the ratio of the probability that the household will be user to the probability that it will be non-user.

Taking the natural log of Eq. (4) above, it is possible to arrive at a log of odds ratio, which is linear not only in $X$ 's but also in the parameters:

$$
\mathrm{Li}=\operatorname{Ln}\left(\frac{P_{i}}{1-P_{i}}\right)=Z_{i}=\beta_{0}+\beta_{j} X_{j i}, \forall j \in V, \forall i \in N
$$

where $P_{i}$ is the probability of being user of microcredit ranging from 0 to $1 ; V$ is a set of explanatory variable and $N$ is the set of all observations; If the disturbance term $\left(U_{i}\right)$ is introduced, the logit model becomes:

$$
Z_{i}=\beta_{0}+\beta_{j} X_{j i}+U_{i}
$$

Finally, the parameters of the model are estimated using the Maximum Likelihood (ML) method [29, 30]. Maddala [30] noted that the ML method is a general method of estimation that is applicable to a large variety of problems. ML method suggests choosing or estimating the value of the parameter that maximizes the logarithm of the likelihood function itself and the same result is obtained. Hosmer and Lemeshew [31] indicated that the method of ML yields value for the unknown parameters, which maximizes the probability of obtaining the observed set of data and such a method, is preferred when we have data at micro or individual level. However, there is a recognition that the OLS techniques can be used when the data set is sufficiently large and are grouped into the interval.

\section{Propensity score matching (PSM)}

This study employed a propensity score matching model to analyze the impact of microcredit utilization on the household's food security. PSM is a non-parametric method that is widely used in the impact evaluation of different interventions [32]. To estimate the average treatment effect on treated (ATT) using the PSM method the following steps such as estimation of the propensity scores, choosing a matching algorithm, checking on common support region, testing the matching balance and sensitivity analysis were employed. The impact of microcredit credit utilization on the food security of rural households was explained as

$$
\tau i=Y_{i}(\mathrm{Di}=1)-Y_{i}(\mathrm{Di}=0)
$$

where $\tau i$ effect because of microcredit utilization, $Y_{i}$ is the outcome (the impact of microcredit utilization on the rural household's food security) and Di is whether rural household $i$ participate in microcredit or not. However, $Y_{i}(\mathrm{Di}=1)$ and $Y_{i}(\mathrm{Di}=0)$ cannot occur simultaneously for the same individual at the same time. Based on this the position household in the treatment either $Y_{i}(\mathrm{Di}=1)$ or $Y_{i}(\mathrm{Di}=0)$ is an unobserved outcome. Hence, analyzing individual treatment effect $\mathrm{ti}$ is difficult. Therefore, estimating the average treatment effects of the population than the person was very important. Among the average treatment effect, the average treatment effect on treated (ATT) was one of the most commonly used in impact assessment [32], and it was described as

$$
\tau_{-} \mathrm{ATT}=E(\tau / D=1)=E[Y(1) / D=1]-E[Y(0) / D=1] .
$$

Here the outcome variable of participant households, $E[Y(1) / D=1]$ is observed. However, the outcome variable of participant households had they not participated, $E[Y(0) / D=1]$ is not observed. Hence, substituting the outcome (total $\mathrm{Kcal} / \mathrm{AE} /$ day of participant households had they not participated) $E[Y(0) / D=1]$, for the outcome (total $\mathrm{Kcal} / \mathrm{AE} /$ day of non-participant households) is impossible in non-experimental impact assessment. This means that the total $\mathrm{Kcal} / \mathrm{AE} /$ day of households from users and nonusers would differ even in absence participation, this leading to a self-selection bias. By deducting $E(Y 0 / D=0)$ from the left and the right side of the equation we can specify the average treatment effect on treated as follow:

$$
\begin{aligned}
E[Y(1) / D=1]= & E[Y(0) / D=1]-E[Y(0) / D=0]=\tau_{-} \mathrm{ATT} \\
& +E[Y(0) / D=1]-E[Y(0) / D=0] .
\end{aligned}
$$

In this case, the terms on the left side are observables and the average treatment effect on treated can determined if and only if $E[Y(0) / D=1]-E[Y(0) / D=0]$ zero. This occurs when there is self-selection bias. To resolve the selection matter in non-experimental impact studies the following two assumptions are required.

Conditional independence assumption It indicates the outcomes are independent of treatment and conditional on $(X i)$. This assumption shows that the selection only depends on observable characteristics that affect both 
the participation decision of households and the outcome variables simultaneously [33].

Common support It refers to the area in which both participant and non-participant households have propensity score values in common. In other words, it is the area that contains the minimum and maximum propensity score of the participant and non-participant groups, respectively. Those observations whose propensity scores is smaller than the minimum and larger than the maximum are discarded from the treatment and control groups [33]. That is $0<P(D=1) / X<1$. Given these two assumptions, the propensity score matching algorithm to estimate ATT can be described as

$$
\begin{aligned}
E[Y(1) / D=1]= & E[Y(0) / D=1]-E[Y(0) / D=0]=\tau_{-} \mathrm{ATT} \\
& +E[Y(0) / D=1]-E[Y(0) / D=0] .
\end{aligned}
$$

where $P(X)$ is the propensity score calculated from covariate $X$. Equation is explained as; the PSM estimators are the difference between the mean of outcomes over common support region.

\section{Definition of variables and working hypothesis Dependent variable}

It is a dummy variable that takes the value 1 for credit user and 0 , otherwise.

\section{Outcome variable}

It is a continuous variable which is the amount of food consumed by individual households in $\mathrm{Kcal} / \mathrm{AE} /$ day for each household.

\section{Independent variables}

The literature reviewed generally indicates that the number of independent variables that can influence household credit utilizations includes; demographic, socio-economic and institutional factors. The definitions and hypothesis of the independent variables are described as follows:

\section{Sex of household head}

It is a dummy variable that takes the value of 1 if the household head is male and 0 , otherwise. Women's lack of control over financial resources and the nature of their financial activities restrict their access to credit from formal institutions. Despite efforts underway to extend credit to women, to bolster their savings, and to provide loans for small business development, evidence suggested that institutional and socio-cultural factors are the major challenges that constrain women from accessing financial services in Ethiopia [34]. For this information, the assumption that male family heads have more access to formal credit as compared to women due to factors they have like more exposure and mobility [35]. Elias et al. [36] and Eshetu [37] found that the gender of the household head had a significant influence on microcredit utilization. The expected influence of sex of the household head on microcredit utilization was hypothesized to be negative.

\section{The religion of the household head}

It is a dummy variable that takes the value of 1 for Muslim and 0 , for Christian. Although the relationship between religion and economic development on the macro-level has been explored, it is less clear how the background of religiosity influences economic attitudes and financial decision-making on the level of the individual or household at the micro-level [38]. The possible reason is that in the Muslim religion, credit or saving is not allowed, since paying or receiving interest is considered as haram [39]. Addis et al. [40] identifies religion as determinant factors in the west Amhara regional state has had its share towards the impact of saving and credit on households. The expected influence of the household's religion on microcredit utilization was hypothesized to be negative for Muslims.

\section{Age of household head}

It is a continuous variable as it is defined by the occurrence of continual aging by the heads of a family when measured in years. Age, as one of the developmental characteristics of human beings, considerably influences the decision-making process. This all influences the use of available resources in the best way to contribute to household asset improvement. The age of the household head has a positive relation with micro-credit utilization [3]. Older farmers have better social networks and associations with formal credit companies [41]. An assumption is made that older farmers have more access to credit as well as more access to the use of credit from formal institutions. The expected effect of age on rural household microcredit utilization was expected to be positive.

\section{The education level of the household}

It is a continuous variable that is measured in years of schooling. Education increases a farmer's" ability to get and use information. Educated farmers may have the ability to analyze costs and benefits and thereby improve their livelihood. According to Tang et al. [41] and Elias et al. [36], farmers who have a better level of schooling have a higher chance of being a participant. It is hypothesized that educated farmers have more access to credit as compared to others. Education was expected to affect microcredit utilization positively. 


\section{Marital status}

It is a dummy variable that takes up the value of 1 , if the household head is married and, 0 otherwise. Marital status has also been shown to affect asset accumulation [42]. Historically, marriage has been viewed as a source of financial security continues to be a determining factor for economic well-being. Pooling resources for a married couple may make them accumulate assets without going under in times of crisis. Ijioma and Osondu [43] also found that unmarried farmers acquired less microcredit than married farmers. This is basically because lenders viewed married farmers as being relatively more stable, responsible and capable of repaying borrowed funds. The expected influence of this variable on rural household credit utilization was positive for married households.

\section{Family size}

It refers to the total number of household members who lived with the household head for at least 6 months and is expressed in adult equivalent. Large productive family size in the rural household generates and enhances the household income of rural households and enables them to be involved in microcredit services. Having a large family size may imply that the household has enough labor supply for participation in different income generating activities, such as microfinance services [20,44]. Elias et al. [36] also argued that households who have several family members are less likely to participate in the microcredit than households with fewer family members. On the other hand, Orebiyi et al. [45] found that large family size may imply self-insufficiency in terms of food consumption, because large households consume more than do small households. The expected effect of family size on microcredit is ambiguous.

\section{Total land size}

This is a continuous variable referring to the total land owned by households in a hectare. The land is one of the important factors for farm production. Currently, land scarcity and lack of alternative non-farm employment opportunities are serious problems in rural areas. Severe land shortage, high levels of landlessness and unemployment are eroding peasant's ability to withstand environmental stresses and food shortages. Elias et al. [36] found that households owning large farm sizes have a lower probability of attaining credit from formal financial institutions. Saqib et al. [46] found that as household who has a larger size of land can utilize more capital and accessed credit. Hence, this variable was expected to have a positive or a negative influence on the dependent variable.

\section{Total livestock ownership}

This is a continuous variable referring to the total number of animals possessed by the household measured in Tropical Livestock Unit (TLU). As the total number of animals in the household increases, the household would be less likely to go for credit. This can be attributed to increasing wealth and income base of farm households which makes more money available in households that minimizes demand for credit [22]. Contrarily, Alemu et al. [47] found that households who owned a large number of livestock is considered as a safe client by lending institution and borrowers themselves are more confident in accessing a loan from the institution. Hence, this variable was hypothesized to have a positive or a negative influence on the dependent variable.

\section{On-farm income}

It is the total amount of money (in Ethiopian Birr) obtained from on-farm income source. On-farm income is an important issue to be considered in economic aspects in the rural area [44]. On-farm income is income that the household earns from the sale of both crop and livestock. As the income of the household increase, the demand for credit utilizes decreases. This finding concurs with the findings of Razan [48], who found on-farm income to be among the important determinants but also concluded that there was a negative relationship between on-farm income and microcredit utilization, because as farmers accumulate more income, they tend to shy away from taking credit. However, in a situation of transitory changes in smallholder farming households' income affects household consumption and hence the need for more funding through credit financial seeking. Saqib [46] indicated that a transitory change on farm income is a factor, which is necessary for a positive effect on access to financial credit services due to its effect on consumption. Therefore, it was hypothesized to influence credit utilization negatively.

\section{Off-farm/nonfarm income}

It is the total amount of money (in Ethiopian Birr) earned from off-farm/non-farm income sources. Described as People with external sources of income rather than from solely farming, tend to take more credit, since they have high-income expectations in the future [44]. In some other situations, some low-income people may borrow more to meet high expenditures, while rich people may not be interested in borrowing a lot. Engaging in nonfarm activities has dual effects on households' productivity and welfare. It is a means of diversifying income sources and earning higher levels of income by investing in high-risk high return activities. Besides, income generated from non-farm activities can be plowed back to 
agriculture with an effect of increasing agricultural productivity [49]. Off-farm/non-farm income was hypothesized to affect credit utilization positively.

\section{Farming experience}

It is continuous variables and it is measured in years of farming experience. As the household head farming experience increase, there is a high probability of obtaining credit [9]. This implies that smallholder farmers who accessed credit had more years of farming experience. Kifle et al. [20] and Saqib et al. [46] revealed that farming experience showed a positive relationship with microcredit, utilization that is, with an increase in farming experience, farmers' access to credit also increased. Therefore, it was hypothesized to influence credit utilization positively.

\section{Frequency of extension contact}

The frequency of extension contact is measured as a continuous variable. This refers to the number of contacts with extension agents that the respondent made in the month. Farmers who have frequent contact with extension agents are expected to have more information that will influence the farm household's demand for credit access from the microfinance institution [22]. Farmers who have frequent contact with extension agents would be expected to have more information that would influence the farm household's demand for credit from the formal sources [46]. Therefore, it was hypothesized to influence credit utilization positively.

\section{The time required to reaching OCSSCO}

It is a continuous variable measured in minutes of walking. Households near financial institutions have a location advantage and can contact easily and have more access to information than those who live more distant locations. Farmers near the lending institutions have a location advantage in saving farm resources (time, labor and money) which otherwise would have been spent to access credit and can contact the lender easily and have more access to information than those who live at more distant locations $[9,36,44]$. Therefore, it was hypothesized that this variable influences the farmer's credit utilization negatively.

\section{Results and discussion}

\section{Description of households characteristics}

Gender is one of the variables that can determine the credit utilization of households. As indicated in Table 2, out of the total sampled households, $61 \%$ were male and the remaining $39 \%$ were female. Table 3 also shows that out of the total sampled non-credit user households, $64 \%$ were female-headed. On the other hand, $41 \%$ of the sampled credit user households were female-headed. The Chi-square result $\left(\chi^{2}=0.743 ; P=0.226\right)$ showed that there was no statistically significant difference between both sexes on credit use. This possibly indicates that male and female-headed households had an equal chance to access information on saving and formal financial institutions make their target on male and female-headed households during credit mobilization.

Of the total sampled household heads, $87 \%$ and $13 \%$ were married and single, respectively (Table 2). Among the non-users, $88 \%$ were married, whereas $12 \%$ of them were single. On the other hand, $86 \%$ of the credit users were married, whereas $14 \%$ of them were single. The Chi-square test indicated that there is no statistically significant association between marital status and credit utilization $\left(\chi^{2}=0.462 ; P=0.301\right)$. Therefore, the result of this study showed that being married or unmarried had no significant effect on credit utilization in the study area. This reveals that married and unmarried household

Table 2 Descriptive statistics of sample households (dummy variables). Source: survey result (2019)

\begin{tabular}{|c|c|c|c|c|c|c|c|c|}
\hline \multirow[t]{2}{*}{ Variable } & \multicolumn{2}{|c|}{ Credit User (171) } & \multicolumn{2}{|c|}{ Non-user (189) } & \multicolumn{2}{|c|}{ Total (360) } & \multirow[t]{2}{*}{$x^{2}$} & \multirow[t]{2}{*}{$P$ value } \\
\hline & $N$ & $\%$ & $N$ & $\%$ & $N$ & $\%$ & & \\
\hline \multicolumn{9}{|l|}{ Gender } \\
\hline Male & 101 & 59 & 120 & 36 & 221 & 61 & $0.743^{\mathrm{NS}}$ & 0.226 \\
\hline Female & 70 & 41 & 69 & 64 & 139 & 39 & & \\
\hline \multicolumn{9}{|c|}{ Marital status } \\
\hline Single & 24 & 14 & 22 & 12 & 46 & 13 & $0.462^{\mathrm{NS}}$ & 0.301 \\
\hline Married & 147 & 86 & 167 & 88 & 314 & 87 & & \\
\hline \multicolumn{9}{|l|}{ Religion } \\
\hline Muslim & 143 & 84 & 153 & 81 & 296 & 82 & $0.439^{\mathrm{NS}}$ & 0.300 \\
\hline Christian & 28 & 16 & 36 & 19 & 64 & 18 & & \\
\hline
\end{tabular}


Table 3 Descriptive statistics of sample households (continuous variable). Source: own field survey (2019)

\begin{tabular}{|c|c|c|c|c|c|c|}
\hline \multirow[t]{2}{*}{ Variables } & \multicolumn{2}{|c|}{ Credit user (171) } & \multicolumn{2}{|c|}{ Non-user (189) } & \multirow{2}{*}{$\begin{array}{l}\text { Overall } \\
\text { Mean }\end{array}$} & \multirow[t]{2}{*}{$t$ value } \\
\hline & Mean & SD & Mean & SD & & \\
\hline Age & 43.36 & 9.89 & 43.02 & 11.35 & 43.18 & $0.303^{\mathrm{NS}}$ \\
\hline Education level & 3.17 & 2.5 & 2.25 & 2.07 & 2.69 & $3.8^{* * *}$ \\
\hline Family size & 6.04 & 1.72 & 5.13 & 1.5 & 5.56 & $5.4^{* * *}$ \\
\hline Farm experience & 23.7 & 9.13 & 22.3 & 11.9 & 22.94 & $1.2^{\mathrm{NS}}$ \\
\hline Land size & 2.07 & 1.4 & 1.70 & 1.38 & 1.88 & $2.5^{* *}$ \\
\hline Livestock holding & 2.9 & 2.13 & 3.4 & 1.99 & 3.14 & $-2.36^{* *}$ \\
\hline On-farm income & 1960 & 1933 & 2435 & 1809 & 2209 & $-2.4^{* *}$ \\
\hline Frequency of Ext. contact & 1.63 & 1.22 & 1.43 & 1.26 & 1.53 & $1.55^{\mathrm{NS}}$ \\
\hline Off/non-farm income & 470 & 675 & 282 & 575 & 372 & $2.8^{* * *}$ \\
\hline The time required to reach OCSSCO & 93.9 & 36.29 & 95.8 & 36.26 & 94.90 & $-0.487^{\mathrm{NS}}$ \\
\hline
\end{tabular}

NS, Non-significant

${ }^{*},{ }^{* *}$ and ${ }^{* * *}$ means significant at $10 \%, 5 \%$ and $1 \%$ probability levels, respectively

heads would have similar socio-cultural background possibly regarding credit utilization.

Religion plays an important role in affecting the credit utilization of rural households. The survey result revealed that $82 \%$ of the sampled households belong to Islam and $18 \%$ of them belong to Christians. Among the total noncredit user households, $81 \%$ were Islam, whereas the remaining 19\% were Christians. Of the total credit users, $84 \%$ were Islam, whereas $16 \%$ were Christian. The result further indicated that $\left(\chi^{2}=0.439 ; P=0.300\right)$ there was no statistically significant association between religion and credit use in the study area.

Table 3 presents the $t$ test results of the continuous variables. The results showed that the overall mean age of the sampled households was 43.18 years. The mean age of the microcredit user and non-user group is 43.36 and 43.02, respectively. The result discloses that the overall mean of the educational level of the households is 2.7. While the mean educational attainment of microcredit users and non-user was found to be 3.17 and 2.25 , respectively. The $t$ test result shows the significant difference between both groups at less than $1 \%$ significance level.

The family size of the household is also an important factor for the microcredit utilization of rural households. Accordingly, the average family size of the sampled household is 5.56 adults. The result indicated that the average family sizes of the credit users and non-users households are 6.04 and 5.13, respectively. The $t$ test result shows that there is a statistically significant difference between users and non-users groups at less than $1 \%$ significant level. On the other hand, the average farm experience of the respondents is 22.94 years. The mean farm experience of credit users and non-users is 23.7 and 22.3 , respectively. The $t$ test result shows that there is no statistical difference between the two groups.
The land size of the household is an important variable that can determine credit utilization in a rural area. The mean land size of the respondents is 1.88 hectares. The mean land size of credit users and non-users households are 2.07 and 1.70 hectares, respectively. The $t$ test result shows there is a statistically significant difference in land size at less than $5 \%$ significant level between the two groups. Livestock is the most important asset for rural households in the study area. The overall mean livestock ownership is 3.14 TLU. The average size of the livestock of the sampled users and non-users are 2.9 and 3.4 TLU, respectively. The $t$ test shows there is a statistically significant difference at less than $5 \%$ significant level between the two groups.

The major sources of on-farm income for the sampled households were crop production and livestock production in the study area. The average on-farm income of the households is 2209.06 ETB. The result of the analysis also shows that the mean on-farm income for credit users and non-users are 1960 and 2435 in ETB, respectively. The $t$ test result shows a statistically significant difference at less than $5 \%$ significant level between credit users and non-users.

The average mean of frequency of extension contact per month in the study area is 1.53 . It was found that microcredit users made contact with agricultural development agents 1.63 times per month while the nonusers contact 1.43 times per month. The overall mean of off-farm/non-farm income respondents is 371.77 ETB. The average off/non-farm income for credit users and non-users are 470 and 282 in ETB, respectively. The mean comparison shows the presence of a significant difference at $1 \%$ significant level between both groups.

The overall average time required to reach OCSSCO microfinance is $94.9 \mathrm{~min}$. The average time required to 
reach OCSSCO travelled by the users and non-users is 93.9 and 95.8 in walking minutes, respectively.

The next sub sections presented the factors the affect smallholder farmers' decision to use microcredit and the potential benefit that microcredit generates on household food security in the study area.

\section{Determinants of microcredit utilization}

Table 4 presents the results of the binary logit regression model. Among 13 variables assumed to determine the use of credit, six were found to be significant.

\section{The education level of household heads}

It was hypothesized that the education level of the household would affect credit utilization positively provide that education increases the analytical ability of individuals to process information received from any source. The result shows that the education level is found to be positively and significantly $(P<0.01)$ influences credit utilization in the study area. The odds ratio in favor of credit utilization increases by a factor of 1.20 as education level increases by one grade. The possible explanation for this finding is that educated households apply their knowledge and skill gained from various sources on credit utilization. These findings are consistent with Abdul-Jalil [3] who found that education has a positive impact on access to credit. On the other hand, this finding contradicts that of Roberts et al. [44] who found the negative influence of education on credit utilization.

\section{Family size of the households}

It was hypothesized that the family size of the household would influence microcredit utilization positively or negatively. The result revealed that family size is found to be positively and significantly $(P<0.01)$ influenced credit utilization in the study area. The odds ratio in favor of microcredit utilization increases by a factor of 1.42 as a family size increases by 1 adult equivalent. This might be due to the fact that larger family size provides labour force who need initial financial capital to start business. This result is in conformity with the prior argument by Isitor et al. [50] which exposed that larger number of family members provides additional labor force to participate in production that require financial capital. Alemu et al. [47] also found that household with larger family size requires more finance to cover different costs associated with different demand arise from this large family size.

\section{Landholding size}

Landholding size was hypothesized to influence microcredit utilization positively or negatively. From the results of these findings, land size is positively significant at $5 \%$ significance level. The odds in favor of credit utilization increases by a factor of 1.23 as households had large cultivated landholdings than those who had lesser landholdings. This disclosed that rural households with large cultivated land size are more likely to utilize credit than those households with less land size. This implies,

Table 4 Binary logistic regression result. Source: Field survey (2019)

\begin{tabular}{|c|c|c|c|c|}
\hline Variables & Coef & Odds ratio & $z$ & $P>Z$ \\
\hline Sex of the household head & -0.4002 & 0.6702 & $-1.62^{\mathrm{NS}}$ & 0.104 \\
\hline The religion of the households head & -0.0752 & 0.9275 & $-0.24^{\mathrm{NS}}$ & 0.812 \\
\hline Age of the household head & -0.0187 & 0.9814 & $-0.97^{\mathrm{NS}}$ & 0.330 \\
\hline Marital status & -0.3318 & 0.7176 & $-0.93^{\mathrm{NS}}$ & 0.352 \\
\hline Education level & 0.1862 & 1.2046 & $3.51^{* * *}$ & 0.000 \\
\hline Family size & 0.3518 & 1.4216 & $4.61^{* * *}$ & 0.000 \\
\hline Farming experience & 0.0225 & 1.0228 & $1.18^{\mathrm{NS}}$ & 0.238 \\
\hline Land size & 0.2029 & 1.2250 & $2.25^{* *}$ & 0.025 \\
\hline Livestock holding & -0.1116 & 0.895 & $-1.94^{*}$ & 0.052 \\
\hline On-farm income & -0.0002 & 0.998 & $-2.28^{* *}$ & 0.023 \\
\hline Frequency of extension contact & 0.1375 & 1.1474 & $1.44^{\mathrm{NS}}$ & 0.149 \\
\hline Off-farm/non-farm income & 0.0004 & 1.0004 & $1.90^{*}$ & 0.057 \\
\hline Time required to reach OCSSCO & -0.0001 & 0.9999 & $-0.03^{\mathrm{NS}}$ & 0.975 \\
\hline Constant & -1.7592 & 0.1722 & -1.98 & 0.047 \\
\hline Pseudo $R^{2}=0.1380$ & & \multicolumn{3}{|l|}{ Log-likelihood $=-214.72$} \\
\hline $\operatorname{LR} \operatorname{chi}^{2}(13)=68.73$ & & \multirow{2}{*}{\multicolumn{3}{|c|}{ Number of obs $=360$}} \\
\hline Prob $>c h i^{2}=0.0000$ & & & & \\
\hline
\end{tabular}

NS not significant

${ }^{*},{ }^{* *}$ and ${ }^{* * *}$ are the significance level at 10,5 and $1 \%$, respectively 
the larger the cultivated land size, the farmers utilize more farm inputs such as labor, fertilizer, and others that demand additional capital that might be obtained through credit. The result agrees with other studies that indicated the total cultivated landholding would increase access to formal credit use $[36,51]$.

\section{Livestock holding}

Livestock holding was hypothesized to affect credit utilization negatively. The result of the study is also in line with the hypothesis. From the results of these findings, livestock holding is significantly influenced credit utilization negatively. This implies that rural households with large livestock sizes are less likely to utilize microcredit than those households with a small amount of livestock. The odds in favor of credit utilization decrease by a factor of 0.895 as household livestock increases by one tropical livestock unit (TLU). The possible explanation is that households who have large numbers of livestock sell their livestock to get cash to be used for different purposes rather than borrow credit from financial institutions. This finding is consistent with the previous findings that livestock holding was found to affect participation in microcredit and farm productivity negatively [36]. In contrast, this finding disagrees with Alemu et al. [47] who found that households who owned a large number of livestock is considered as a safe client by lending institution and borrowers themselves are more confident in accessing a loan from the institution.

\section{On-farm income}

On-farm income was hypothesized to affect microcredit utilization negatively. The results of this study are also in line with this hypothesis. From the results of these findings, on-farm income was significantly influenced credit use negatively. The result shows that the probability of credit utilization decreases by a factor of 0.998 as households on-farm income increase by one Ethiopian Birr (ETB). This revealed that rural households who earn more income are less likely to utilize microcredit than those households with less amount of income. The possible explanation for this is that the more income the farmer earns, the less likely he/she will go for external funds. This result is substantiated by Ukpe [52] that showed farm income is one of the factors that had a significant negative influence on household's access to microcredit.

\section{Off-farm/non-farm income}

The main source of off-farm/nonfarm income in the study area was petty trade, wage labor, and handcrafts. It is hypothesized to influence credit utilization either positively or negatively. The results of this finding, i.e.,
Table 5 Mean and mean differences in calorie intake. Source: Survey result (2019)

\begin{tabular}{llllll}
\hline Variables & $\begin{array}{l}\text { Credit } \\
\text { users }\end{array}$ & $\begin{array}{l}\text { Credit } \\
\text { non-users }\end{array}$ & $\begin{array}{l}\text { Mean } \\
\text { difference }\end{array}$ & $\begin{array}{l}\text { Combined } \\
\text { mean }\end{array}$ & t test \\
\hline $\begin{array}{l}\text { Food calo- } \\
\text { rie }\end{array}$ & 2374.9 & 2207.45 & 167.413 & 2287 & $5.25^{*}$ \\
$\begin{array}{l}\text { intake/ } \\
\text { AE/Day }\end{array}$ & & & & & \\
\hline
\end{tabular}

${ }^{*}$ Significant at $10 \%$ probability level

Table 6 Distribution of households by their energy consumption. Source: survey result (2019)

\begin{tabular}{llllll}
\hline $\begin{array}{l}\text { Category of the } \\
\text { households }\end{array}$ & \multicolumn{2}{l}{$\begin{array}{l}\text { Food secured (Kcal/AE/ } \\
\text { day) }\end{array}$} & \multicolumn{2}{l}{$\begin{array}{l}\text { Food insecure } \\
\text { (Kcal/AE/day) }\end{array}$} \\
\cline { 2 - 3 } Credit user & Min & Max & & Min & Max \\
\hline Credit non-user & 1864 & 3171 & & 1694.6 & 2193.2 \\
\hline
\end{tabular}

is off-farm/non-farm income found to influence credit use significantly in a positive way. The result shows that as off-farm/nonfarm income of the household increases by 1 Ethiopian Birr (ETB) the odd in favor of microcredit utilization increases by a factor of one. The study result reveals that rural households with more off-farm/nonfarm income are more likely to utilize microcredit than those households with less off-farm/non-farm income. The possible explanation for these variables is that households in rural area who have been earning more offfarm/non-farm income need to diversify their non-farm activities, because scarcity of land prohibits them to participate in farm activities. The result of this study is consistent with Alemu et al. [47] who found that households who engaged in nonfarm activities may be innovative and rely on external finance to expand their businesses. To expand their businesses, they need more financial sources. Hence, they are more likely to participate in microcredit and also have more interest to expand their businesses (Table 4).

\section{Household food security status}

Table 5 demonstrates the mean and mean difference of food in calorie intake/AE/day between credit users and non-users. The mean calorie intake/AE/day of credit users and non-users households was 2374.9 and 2207.45, respectively. The result also illustrates that there is a significant difference at $10 \%$ probability significance level of food intake/AE/day between microcredit users and non-users households. As indicated, the mean difference in calorie intake/AE/day between users and non-users households was $167.41 \mathrm{Kca} / \mathrm{AE} /$ day. 
According to Table 6, the minimum and maximum energy available for food secured micro-credit users households were 1864 and $3171 \mathrm{kcal} / \mathrm{AE} / \mathrm{day}$, respectively. In addition, the minimum and maximum energy available for food-in secured microcredit user's households was 1694.6 and $2193.2 \mathrm{kcal} / \mathrm{AE} /$ day, respectively. Besides, credit non-user households, the minimum and maximum available energy for food secured microcredit non-users households was 1564 and $2970.7 \mathrm{kcal} / \mathrm{AE} /$ day, respectively. Moreover, the minimum and maximum energy available for food-insecured microcredit non-user households were $1531.8 \mathrm{kcal} / \mathrm{AE} /$ day and $2198.3 \mathrm{kcal} / \mathrm{AE} /$ day, respectively.

By taking $2200 \mathrm{kcal} / \mathrm{AE} /$ day into account, as a standard, only 216 sample households' (60\%) were able to meet the minimum subsistence requirement and 144 households' (40\%) were, found to be unable to meet their minimum subsistence requirement. From credit user households, 45(26\%) and 126 (74\%) were food insecured and food secured, respectively. From credit non-users, 99(52\%) and 90(48\%) were food insecured and food secured, respectively. The result is less than the findings of Muche and Esubalew [53] who found that $65 \%$ and $35 \%$ of the households in Jimma zone were food insecured and food secured, respectively. Thus, from the current study food insecurity status was declined from 65 to $40 \%$ in the Jimma zone. The possible explanation for the turndown of food insecurity was due to the fact that households are started using credit to make themselves food secured. The result of this study was also consistent with the national level study of food security [54] that found, in Ethiopia 40\% of households were food energy deficient, using the threshold of 2,550 kilocalories per adult equivalent per day (Fig. 2).

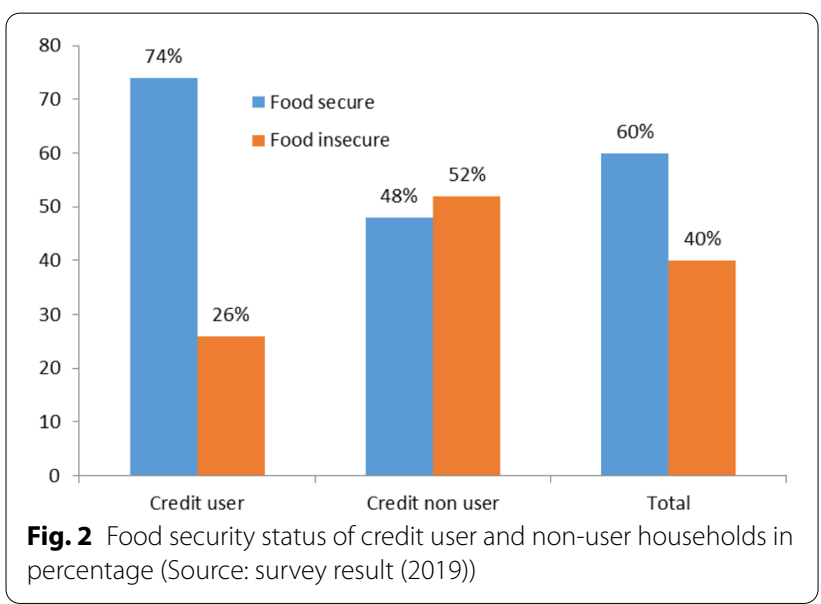

\section{Impacts of microcredit utilizations on household food security Identifying common support region}

According to Table 7, the propensity scores vary between 0.070 and 0.968 for microcredit users with the mean of 0.568 , whereas the score varies between 0.052 and 0.854 for non-credit user households with the mean score of 0.391. Then, the common support lies between 0.070 and 0.854 . This means that a household whose propensity score less than the minimum (0.070) and larger than maximum (0.854) are not considered for matching purposes. Based on this procedure, 19 households from the microcredit user group were discarded from the study for the impact assessment procedure.

\section{Matching microcredit users with non-users household}

Different matching algorithms were tried in matching microcredit users with non-user households in common support regions. The final choice of matching algorithm was guided by three criteria: namely, equal mean test (balancing test), pseudo $R^{2}$ and size of the matched sample. Matching algorithm which balances all explanatory variables of groups (result in insignificant mean differences between both groups), bears low pseudo $R^{2}$ value and results in a large sample size is preferable [55]. Based on those criteria, Kernel Matching with a bandwidth of (0.1) was found to be the best estimator for this study. Therefore, the impact analysis procedure was followed and discussed using Kernel Matching with a bandwidth of (0.1).

\section{Verifying the common support condition}

Figure 3 gives the histogram of the estimated propensity scores for users and non-users of microcredit. A visual inspection of the density distributions of the estimated propensity scores for the two groups indicates that the common support condition is satisfied: there is substantial overlap in the distribution of the propensity scores of both users and non-users groups. The bottom half of the graph shows the propensity scores distribution for the non-users and the upper half refers to the users. The densities of the scores are on the $y$-axis.

Note: "Treated/untreated: on support" indicates the observations in the user group that have a suitable

Table 7 Distribution of estimated propensity score of households. Source: Field survey

\begin{tabular}{llllll}
\hline Group & Observation & Mean & STD & Min & Max \\
\hline All households & 360 & 0.475 & 0.210 & 0.052 & 0.967 \\
Treated households & 171 & 0.568 & 0.206 & 0.070 & 0.968 \\
Control households & 189 & 0.391 & 0.176 & 0.052 & 0.854 \\
\hline
\end{tabular}




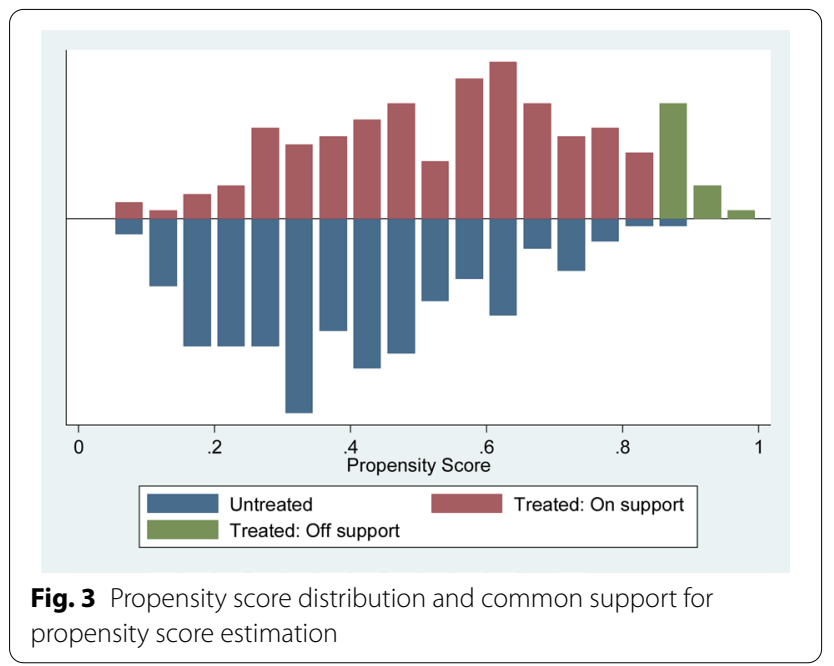

comparison and off support indicates the observations in the user group that have no suitable comparison.

\section{Testing of the balance of propensity score}

After selecting best performing matching algorithm which satisfies prior identified performance criteria, the balance of propensity score and explanatory variables was checked by the selected matching algorithm (Kernel Matching With a bandwidth of (0.1, in this case). The main intention of estimating propensity score is not to get a precise prediction of selection into treatment. Rather, to balance the distributions of relevant variables in both groups [33]. Therefore, the selected matching algorithm, Kernel Matching with a bandwidth of (0.1) has created a covariate balance between microcredit users and non-users households, which is important to conduct impact analysis.

As it is indicated in Table 8, the value of pseudo- $R^{2}$ was very low. The low pseudo- $R^{2}$ value and the insignificant likelihood ratio test indicate that microcredit user households and non-user households had the same distribution in the covariates after matching. The results indicate that the matching procedure can balance the characteristics in treated and the matched comparison groups. Hence, these results can be used to assess the impact of microcredit among groups of households having similar observed characteristics. This enables to compare observed outcomes for

Table 8 Propensity score matching: quality test. Source: Field result (2019)

\begin{tabular}{lccc}
\hline Sample & Ps $\boldsymbol{R}^{\mathbf{2}}$ & LR chi2 & $\boldsymbol{p}>$ chi2 \\
\hline Unmatched & 0.138 & 68.96 & 0.000 \\
Matched & 0.006 & 2.70 & 1.000 \\
\hline
\end{tabular}

microcredit users with those of a non-user group sharing common support.

Thus, all of the above tests suggest that the matching algorithm chosen was relatively best for data of this study. Therefore, it was possible to proceed to estimate the average treatment effect on the treated (ATT) for sample households.

\section{Sensitivity analysis}

Deciding which variables should be included in a statistical model is one of the unsolved and probably most debatable issues in an observational study [33]. It is, of course, well known that relevant but omitted variables cause bias in the outcome of the intervention. The standard response to this knowledge has been to include additional control variables under the belief that the inclusion of every additional variable serves to reduce the potential threat from omitted variable bias. However, the reality is more complicated, and the control variable strategy does not protect from omitted variable bias. To reduce this problem, sensitivity analysis has a great advantage [33]. To check for unobservable biases, a sensitivity analysis was performed on the computed outcome variables using the Rosenbaum Bounding approach concerning deviation from the conditional independence assumption. The basic question to be answered here is whether inference about treatment effects may be affected by unobserved factors (hidden bias). The result shows that the inference for the impact of microfinance interventions is not changing through the participants and non-participant households have been allowed to differ in their odds of being treated up to $100 \%$ at critical sigma 2 in terms of unobserved covariates. Thus, it is possible to conclude that impact estimates (ATT) of this study for each outcome variables were insensitive to unobserved selection bias.

Thus, we can conclude that our impact estimates (ATT) are not sensitive to unobserved selection bias and is a pure effect of microcredit utilization (Table 9).

\section{Estimating average treatment effect on treated (ATT)}

To attain the stated objective, the following impact indicators of the treatment effect have been performed using the already mentioned PSM model. The estimation result presented in Table 10 provides supportive evidence of a statistically significant effect of the program on households' food

Table 9 Result of sensitivity analysis using Rosenbaum bounding approach. Source: Field Survey (2019)

\begin{tabular}{llllll}
\hline Outcome & $\boldsymbol{e}^{\gamma}=\mathbf{1}$ & $\boldsymbol{e}^{\gamma}=\mathbf{1 . 2 5}$ & $\boldsymbol{e}^{\gamma}=\mathbf{1 . 5}$ & $\boldsymbol{e}^{\gamma}=\mathbf{1 . 7 5}$ & $\boldsymbol{e}^{\gamma}=\mathbf{2}$ \\
\hline HH Kcal/AE/day & 0.000 & 0.000 & 0.000 & 0.000 & 0.000
\end{tabular}


Table 10 Average treatment effect on the treated (ATT) estimation results. Source: Survey result (2019)

\begin{tabular}{lllllll}
\hline Outcome Variable & Sample & Treated & Controls & Difference & S.E & T-stat \\
\hline Mean HHFS in Kcal/AE/day & Unmatched & 2374.887 & 2207.474 & 167.413 & 31.912 \\
& ATT & 2384.888 & 2207.890 & 176.998 & $3.25^{*}$ \\
& & & & $4.68^{* *}$ \\
\hline
\end{tabular}

security. A positive value of average treatment effect on the treated (ATT) indicates that the households' food security status in $\mathrm{Kcal} / \mathrm{AE} /$ day has been improved as a result of microfinance program intervention in the study area. By controlling other variables, it has been found that the program has increased the food security status of the households by $176.998 \mathrm{kcal} / \mathrm{AE} /$ day.

That means the program has increased the calorie intake of the participating households by more about $7.05 \%$ from what they would have consumed in the absence of the program. This is in line with the objective of MFIs, which is improving food security at the household level [13]. This is obvious that the Kcal/AE/ day of credit user households is fairly higher than those of households in all propensity score matching methods. Therefore, the research hypothesis which says microcredit participation increases the food security status of borrowers is accepted at 5\% level of significance for all with t-statistics of 4.68, accordingly. This is in line with some impact studies on microcredit that have found positive significant impacts of microcredit utilization on the income and consumption of the household [56-59].

The results from FGD were also supporting these findings. During FGD, 47-year male credit user household explained that; "Last year I took credit from OCSSCO and bought an ox. The ox helped me to plow additional land that I have rented from another farmer. I have got a good harvest so that I paid back my loan by selling the crops that I harvested. Therefore, credit helped me to plow additional land and increase my production".

The credit users 51 age male during FGD said that "I was a very poor person. Our family life was miserable. However, after I got a loan from OCSSCO our livelihood improved. I feed my families properly. I develop confidence. I can send my children to school. Last year my child graduated with his college diploma and he acknowledged OCSSCO more than me. Credit users 42 age woman during FGD has raised the negative impacts of microcredit utilization on their family. 'Last year we took about 4000 birr credit from OCSSCO for livestock investment. But we used half of the loan to purchase grains as we did not have enough to eat. We used the remaining half of the loan to buy 2 sheep. We hoped to pay back the credit from the money that we will get from sheep breeding. But we were not lucky. Two of the sheep's died from disease and we sold our cow to pay back our loan so that we can get a loan next time.'

\section{Conclusions and policy implications}

The study attempted to analyze the impact of microcredit use on household food security in the study area. A non-parametric method that uses the application of a binary propensity score matching estimator was used. The results of this study indicate that education status, family size, land size, off-farm/non-farm income, and livestock holding are the most important factors that determine household's decision to use microcredit service.

The PSM result reveals that microcredit has brought a positive impact on the food security of households. The result further reveals that credit user households were more food secure than non-users in the study area. This suggests that microcredit utilization has an important influence on rural household food security. From this study, we concluded that microcredit utilization is one of the viable solutions to improve the food insecurity problem in the study area. However, there existed a significant number of farmers left to enjoy the full benefit of micro-credit due to various reasons. This study opens a window for policy to further expand credit service to reach-out to those who are unable to use it yet. Besides expanding farmers' access to credit, it is also imperative to effectively work on improving education service and increasing the working hours of households per day to enhance their input needs. It is also advised that rural institutions and policies concerned on rural land access should facilitate an opportunity to access more land in the form of land renting, contracting, and sharecropping. Finally, the results highlighted the importance of creating alternative livelihood options to enhance household food security. To meet the intended goal of micro-finance institutions, the government should emphasize policies aimed at increasing opportunities for off-farm/non-farm activities that in turn create employment opportunities. Finally, this paper posed a concern to further investigate the differential impact of microcredit on household food security status on different segments social groups that includes women/men, poor/rich, and boys/girls. 


\section{Acknowledgements}

We wish to express our profound gratitude to Jimma University College of Agriculture and Veterinary Medicine for the financial support in accomplishing this paper.

\section{Authors' contributions}

AA generated the idea, designed the study, and drafted the manuscript. AB has led the overall activities of the research process, such as designing the study, data collection, analysis, interpretation and writing the draft manuscript; BG oversee data collection and provide critical comments; $Y B$ and TC have made significant contribution by providing constructive guidance, and critical comments. All authors read and approved the final manuscript.

\section{Funding}

All data collection, data analysis, and write-up of the study were supported by Jimma University College of Agriculture and Veterinary Medicine.

\section{Availability of data and materials}

Data sharing is not applicable to this article as no data sets were generated or analysed during the current study.

\section{Declarations}

\section{Ethics approval and consent to participate}

Not applicable.

\section{Consent for publication}

Not applicable.

\section{Competing interests}

The authors declare that they have no competing interests.

\section{Author details}

'Department of Rural Development and Agricultural Extension, Jimma University College of Agriculture and Veterinary Medicine, P.O.Box 307, Jimma, Ethiopia. ${ }^{2}$ Department of Agricultural Economics and Agri-Business Management, Jimma University College of Agriculture and Veterinary Medicine, P.O.Box 307, Jimma, Ethiopia.

Received: 20 October 2020 Accepted: 8 July 2021

Published online: 19 November 2021

\section{References}

1. FAO. The State of Food Insecurity in the World 2014: strengthening the enabling environment for food security and nutrition. Rome: FAO; 2014.

2. Omotesho AO, Fakayode SB, Tariya Y. Curtailing ertilizer carcity and climate change; an appraisal of factors affecting organic materials use option in Nigeria's agriculture. Ethiop J Environ Stud Manage. 2012;5(3):281-90

3. Abdul-Jalil MA. Determinants of access to credit and its impact on household food security in Karaga district of the Northern Region of Ghana. 2015; Doctoral Dissertation, Kwame Nkrumah University of Science and Technology.

4. Santeramo FG, Di Pasquale J, Contò F, Tudisca S, Sgroi F. Analyzing risk management in Mediterranean Countries: the Syrian perspective; 2012.

5. FAO. El Niño Response Plan 2016. Addis Ababa: FAO; 2015.

6. Agbola FW, Acupan A, Mahmood A. Does microfinance reduce poverty? New evidence from North-eastern Mindanao, the Philippines. J Rural Stud. 2017;50:159-71.

7. Karlan D, Zinman J. Microcredit in theory and practice: using randomized credit scoring for impact evaluation. Science. 2011;332(6035):1278-84.

8. Sadick M, Egyir IS, Amegashie DPK. Social capital and access to credit by farmer based organizations in the Karaga District of Northern Ghana. J Econ Sustain Dev. 2013;4(16):146-55.

9. Djoumessi YF, Kamdem CB, Afari-sefa V, Bidogeza JC. Determinants of smallholder vegetable farmers credit access and demand in Southwest region, Cameroon. Econ Bull. 2018;38(2):1231-40.
10. Malik HN, Luqman M. Impact of micro credit on women empowerment: a review paper. Pak J Agric Sci. 2005;42(3-4):100-5.

11. NBE (National Bank of Ethiopia). Second quarter report 2017/18. Addis Ababa: NBE; 2018.

12. Danbobi N. Financial inclusion through micro finance, Jimma, Ethiopia; 2017.

13. OCSSCO. Annual performance report. Jimma: OCSSCO; 2019.

14. Torban TK. Assessment of credit risk management in micro finance institutions: a case of Adama Town MFIs, Ethiopia. Srusti Manag Rev. 2020;13(1):42-53

15. Getaneh G. Sustainable Rural Finance: Prospects, Challenges and Implications. In: A paper presented for the association of Ethiopian Microfinance Institutions (AEMFI) Bi-annual conference on the future of microfinance in the New Ethiopian Millennium, Assosa, Ethiopia; 2008.

16. Siyoum AD, Hilhorst D, Pankhurst A. The differential impact of microcredit on rural livelihoods: a case study from Ethiopia. Int J Soc Dev Sustain. 2012;1(3):1-9.

17. Deribe E, Nigussie G, Abddisa MF. Filling the breach: microfinance. J Bus Econ Manag. 2013;1(1):010-7.

18. Sida A. The role of microfinance institutions in improving livelihood: In case of Oromia Credit and Saving Share Company in Agaro Town. Jimma: GRIN Verlag; 2014.

19. Dereje K, Yenenesh T, Sisay B, Jemal Y. Determinants of women's participation in microfinance services: empirical evidence from rural Dire Dawa, Ethiopia. Afr J Agric Econ Rural Dev. 2013;1(1):1-7.

20. Kifle D, Tadesse Y, Belay S, Yousuf J. Determinants of women's participation in microfinance services: empirical evidence from Rural Dire Dawa, Ethiopia. Afr J Agric Econ Rural Dev. 2013;1(1):1-7.

21. Geleta TE, Mengistu AA, Gesese SA. Analysing the impact of credit on rural households' income in the case of Cheliya District, West Shoa Zone, and Oromia National Regional State, Ethiopia. J Glob Econ. 2018;6(3):304. https://doi.org/10.4172/2375-4389.1000304.

22. Temesgen F, Duguma $H$, Hailu C. Factors affecting credit use for rural farming at household level: evidence from small holder farmers' of TokeKutaye district. J Agric Econ Dev. 2018;7(2):007-12.

23. Dirsan N. The Role of microfinance institution in women's household decision making in AdamaWoreda: the case of Oromiya Credit and Saving Share Company Microfinance Institution. 2016; A Thesis Submitted to the School of Graduate Studies of Addis Ababa University in Partial Fulfilment of the Requirements for the Degree of Master of Arts in Sociology.

24. Regassa D, Negash R. Outreach and financial performance of microfinance institution in case of Seka Cokorsa Woreda of Jimma zone. Glob Manag Bus Res. 2014;14(C-4):1-17.

25. Sabit JM, Mohammed A. Role of credit and saving Share Company in poverty reduction in rural communities of Gumay district, Jimma zone, South West Ethiopia. Int J Appl Econ Fin. 2015;9(1):15-24.

26. CSA (Central Statistical Agency). Population projection of Ethiopia for all regions at wereda level from 2014-2017. Addis Ababa: Central Statistical Agency of Ethiopia; 2017.

27. Ephrem T. Zonal diagnosis and intervention plan report for Jimma Zone. A research report, LIVES Project, International Livestock Research Institute, Ethiopia; 2013.

28. Kothari CR. Research methodology: Methods and techniques. New Delhi: New Age International (P) Ltd. Publishing; 2004.

29. Gujirati DN. Basic econometrics. 3rd ed. New York: McGraw-Hill Co; 1995.

30. Maddala GS. Introduction to econometrics: business economics. 2nd ed. New York: Florida University; 1981.

31. Hosmer DW, Lemeshew. Applied logistic regression. New York: A Wiley. Inter-science Publication; 1989.

32. Heckman JJ, Vytlacil EJ. Econometric evaluation of social programs, part II: using the marginal treatment effect to organize alternative econometric estimators to evaluate social programs, and to forecast their effects in new environments. Hand Book of Econ. 2007;6:4875-5143.

33. Caliendo M, Kopeinig S. Some practical guidance for the implementation of propensity score matching. J Econ Surv. 2008;22(1):31-72.

34. Population Council and UNFPA. Ethiopia gender survey: a study in seven regions. Addis Ababa, Ethiopia; 2010. http://www.popcouncil.org/uploa ds/pdfs/2010PGY_EthiopiaGenderSurvey.pdf. 
35. Nwaru JC. Determinants of informal credit demand and supply among food crop farmers in AkwalbomState, Nigeria. J Rural Community Dev. 2011;6(1):129-39.

36. Elias S, Ahmad IM, Patil BL. The determinants of access to agricultural credit for small and marginal farmers' in Dharwad district, Karnataka, India. Res J Agric For Sci. 2015;3(5):1-5.

37. Eshetu OM. Determinants of credit constraints in Ethiopia (Master's thesis, UiT Norges arktiske universitet; 2016.

38. Yizengaw YS, Okoyo EN, Beyene F. Determinants of livelihood diversification strategies: the case of smallholder rural farm households in Debre Elias Woreda, East Gojjam Zone. Ethiop Afr J Agric Res. 2015;10(19):19982013. https://doi.org/10.5897/AJAR2014.9192.

39. Gobezie G, Gumuz B. Sustainable rural finance: prospects, challenges and implications. Int NGO J. 2009;4:012-26.

40. Addis F, Belete B, Bogale M. Rural farm household saving habit in Ethiopia: evidence from South West Amhara growth corridor. Acad J Econ Stud. 2019;5(3):112-9.

41. Tang S, Guan Z, Jin S. Formal and informal credit markets and rural credit demand in China. In: Paper presented at the agricultural and applied economics association. AAEA, CAES and WAEA joint annual meeting, Denvere, Colorado; 2010.

42. Grinstein-Weiss M, Zhan M, Sherraden M. Saving performance in individual development accounts: does marital status matter? J Marriage Fam. 2006:68(1):192-204. https://doi.org/10.1111/j.1741-3737.2006.00241.x.

43. Ijioma JC, Osondu CK. Agricultural credit sources and determinants of credit acquisition by farmers in Idemili Local Government Area of Anambra State. J Agric Sci Technol. 2015;5(1):34-43.

44. Roberts LC, Otieno DJ, Nyikal RA. An analysis of determinants of access to and use of credit by smallholder farmers in Suakoko District, Liberia. Afr J Agric Res. 2017;12(24):2093-100.

45. Orebiyi JS, Henri-Ukoha A, Ben-Chendo NG, Tasie CM, Ekine DI. Determinants of credit supplied by IFAD to rural farmers beneficiaries in Rivers State, Nigeria. Int J Agric Econ Manag Dev. 2012;2:84-6.

46. Saqib SE, Kuwornu JK, Panezia S, Ali U. Factors determining subsistence farmers' access to agricultural credit in flood-prone areas of Pakistan. Kasetsart J Soc Sci. 2018;39(2):262-8.

47. Alemu A, Tefera T, Tasewu W. Impact of microcredit on selected livelihood assets of rural households: the case of Shebedino District Omo microfinance institution, Sidama Zone of Southern. J Econ Sustain Dev. 2018; 9 (3).
48. Razan IS. The Impact of Microfinance on Poverty Alleviation: A Case Study of Borrowers in Ramallah. This thesis was submitted in partial fulfilment of the requirements for the Master's Degree in Economics from the Faculty of Graduate Studies at Birzeit University, Palestine; 2017.

49. Anang BT. Effect of off-farm work on agricultural productivity: empirical evidence from northern Ghana. Agric Sci Technol. 2019;11(1):49-58. https://doi.org/10.15547/ast.2019.01.008.

50. Isitor US, Babalola DA, Obaniyi KS. An analysis of credit utilization and farm income of arable crop farmers in Kwara State, Nigeria. Glob J Sci Front Res. 2014;14(10):26-34.

51. Lemessa A. Analysis of factors affecting smallholder farmers' access to formal credit in Jibat District, West Shoa Zone, Ethiopia. Int J Afr Asian Stud. 2016;25:43-53.

52. Ukpe OU. Effects of access to microcredit on the food security status of crop farm households in Niger Delta, Nigeria. Department of agricultural economics, university of Nigeria, Nsukka; 2016

53. Muche M, Esubalew T. Analysis of household level determinants of food security in Jimma zone, Ethiopia. J Econ Sustain Dev. 2015;6(9):230-40.

54. CSA and WFP. Comprehensive food security and vulnerability analysis. Addis Ababa: CSA; 2014

55. Deheja R, Wahba S. Propensity score-matching methods for nonexperimental causal studies. Rev Econ Stat. 2002;84(1):151-61.

56. Ayelech $\mathrm{E}$. An assessment of the role of micro finance institution in urban poverty alleviation: (The case of addis credit and saving institution in Kirkos Sub City), Addis Ababa University; 2010. http://www.localhost:80/ xmlui/handle/123456789/7355.

57. Ferdousi F. Impact of microfinance on sustainable entrepreneurship development. Dev Stud Res. 2015;2(1):51-63. https://doi.org/10.1080/ 21665095.2015 .1058718$.

58. Samer S, Majid I, Rizal S, Muhamad MR, Sarah-Halim, Rashid N. The impact of microfinance on poverty reduction: empirical evidence from Malaysian perspective. Proc Soc Behav Sci. 2015;195:721-8.

59. Haque A, Das A, Rahman A. The effectiveness of micro-credit programmes focusing on household income, expenditure and savings: Evidence from Bangladesh. J Comp. 2017;9(2):34-44.

\section{Publisher's Note}

Springer Nature remains neutral with regard to jurisdictional claims in published maps and institutional affiliations.
Ready to submit your research? Choose BMC and benefit from:

- fast, convenient online submission

- thorough peer review by experienced researchers in your field

- rapid publication on acceptance

- support for research data, including large and complex data types

- gold Open Access which fosters wider collaboration and increased citations

- maximum visibility for your research: over $100 \mathrm{M}$ website views per year

At BMC, research is always in progress.

Learn more biomedcentral.com/submissions 